\title{
Erratum to: Analysis of critical ricochet angle using two space discretization methods
}

\author{
Kamran Daneshjou $\cdot$ Majid Shahravi
}

Published online: 20 October 2009

(C) Springer-Verlag London Limited 2009

Erratum to: Eng Comput (2009) 25:191-206

DOI 10.1007/s00366-008-0118-x

This article has been retracted due to copyright issues that cannot be resolved.

The online version of the original article can be found under doi:10.1007/s00366-008-0118-x.

K. Daneshjou $(\bowtie) \cdot$ M. Shahravi

Department of Mechanical Engineering, Iran University

of Science and Technology, Tehran, Iran

e-mail: kdaneshjo@iust.ac.ir 